\title{
Tarihsel Romana Genel Bakış ve Dominique Baudis'nin Cebelitarık Âşıkları'nda Ülkü-Arzu Çatışması Üzerine Bir İnceleme
}

\author{
Arş. Gör. Fatih Aynace \\ Aksaray Üniversitesi, Ĕgitim Fakültesi \\ Yabancı Diller Ĕ̆itimi Bölümü \\ fatihayn@hotmail.com
}

Öz

XIX. yüzyıldan günümüze uzanan süreçte popülerliğini her geçen gün artıran tarihsel roman, bazı edebiyat bilimciler tarafından roman türünün özgül ağırlığı karşısında vasat düzeyde bir anlatı türü olarak ele alınırken, çoğu edebiyat bilimciye göre ise, romanın bir alt türü olarak kabul edilir. Türün sözcük yapısı incelendiğinde, nesnelliğin ve olgusallığın yansıması olarak değerlendirilebilecek "Tarih" disiplini ile, öznelliği ve hayâl gücünü temsil eden "Roman" türünün birleşimi söz konusudur. Bu nedenle disiplinlerarası kaynaşmaya örnek oluşturduğu söylenebilir. Roman türünün gerçek hayattan kesitler sunduğu düşünüldügünde, tarihsel roman, okuru gerçeklikle daha yakından yüzleştiren bir edebî tür olarak kendini gösterir. Buna karşın, anlatılarda kurgunun her zaman bir adım önde ilerlediği görülür. Modern anlamda tarihsel romanın İngiltere'de başladığı bilinmesine rağmen, Fransız edebiyatında da seçkin örnekleri bulunmaktadır. Esasen bir siyasetçi olan Dominique Baudit'nin 2010 Prix Mediterranée ödülüne layık görülen Cebelitarık Asşıkları (Les Amants de Gibraltar, 2010) adlı romanı da bu örnekler arasında sayılabilir. Romanda anlatı kişileri arasında çeşitli konularda duygular ve eylemler düzeyinde cereyan eden bazı çatışmalara rastlanmaktadır. Genel olarak ülkü ve arzu kavramları üzerinden sınıflandırılabilecek bu çatışmalar, doğurduğu olumlu ya da olumsuz sonuçlar nedeniyle anlatı kişilerinin yaşamını etkilemektedir. Bu bağlamda Dominique Baudit'nin söz konusu tarihsel romanının incelendiği bu çalışmada, öncelikle tarihsel romandan, tarihsel romanın gelişiminden bahsedilmiş, ardından tematik inceleme konusu olarak ülkü ve arzu kavramları incelendikten sonra, kişi ve olaylar çerçevesinde bu kavramların anlatıdaki yansımalarına değinilmiştir. Yararlılık ve kalıcılık bakımından ülkü kavramının olumlu bir yönünün olduğu, buna karşın bireye ruhen zarar vermesi ve geçiciliği simgelemesi nedeniyle arzu kavramının olumsuz bir içeriğe sahip olduğu vurgulanmıştır.

Anahtar Kelimeler: Tarihsel roman, kurgusal gerçeklik, ülkü, arzu, çatışma.

\section{General View to Historical Novel and an Investigation on the Ideal-Desire Conflict in Les Amants de Gibraltar of Dominique Baudis}

\footnotetext{
Abstract

While the historical novel, which has increased its popularity day by day, is considered by some specialists as a mediocre narrative genre, according to most specialists, 
it is considered as a subgenre of the novel. It is a combination of the "History" being a reflection of objectivity and factivity with the "Novel" representing subjectivity and imagination. As the novel presents sections from real-life, historical novel shows up as a literary genre that brings together the reader with reality. Nevertheless, it is seen that fiction is more dominant. French politician Dominique Baudit's novel Les Amants de Gibraltar (2010), which is awarded 2010 Prix Mediterranée, can be indicated among these examples. In the novel, there are some conflicts among the narrative characters on various issues within the frame of emotions and actions. These conflicts, which are generally shaped around the concepts of ideal and desire, affect the lives of personages because of their positive or negative consequences. In this context of the study where the historical novel in of Dominique Baudit is examined, the development of the historical novel is explored first. Then, the concepts of ideal and desire as the subjects of thematic examination are analysed. It is consequently revealed that the ideal has a positive aspect in terms of usefulness and permanence, whereas the desire has a negative content due to its harmful influences and temporary results.

Keywords: Historical novel, fictional reality, ideal, desire, conflict. 


\section{GíRIŞ}

Kurgusal gerçeklik kavramı, uzunca bir süredir edebiyat dünyasında bahsi geçen ve gerçekliğin ölçütünün ne olacağına ilişkin çeşitli görüşlerin ileri sürüldüğü çok yönlü bir konudur. Özellikle XIX. yüzyılda Realizm (Gerçekçilik) ve Natüralizm (Doğalcılık) akımlarının ortaya çıkmasıyla gündeme gelen bu kavramın, okurun kendinden ya da toplumsal yaşamdan izler bulabilmesi için romanın içeriğinde mutlaka bulunması gerektiği düşünülmüştür. Realist ve Natüralist eğilimin salık verdiği bu yönelim, Yeni Roman gibi yenilikçi edebî anlayışların öne sürdükleri düşüncelerle sarsılsa da, günümüze kadar canlılığını korumayı başarmıştır. Bu sarsıntılı süreçten büyük ölçüde kendini koruyabilmiş olmasına karşın, geçen zaman içinde değişen bireysel ve toplumsal yaşayış, gerçekliğin anlatımında birtakım değişimlerin yaşanmasına neden olmuştur. Bu bağlamda daha önce olduğu gibi yaşanılan zamanın gerçekleriyle yoğrulmuş bir anlatıdan ziyade; yaşanmış, geride kalmış zamanın gerçekleriyle harmanlanmış bir kurgu anlayışı ön plana çıkmaya başlamıştır. Dolayısıyla deneyimlenmiş geçmişi temsil eden "Tarih" ile, olması muhtemel olanı simgeleyen "Kurgu" arasında kurgusal gerçeklik deyimini tam anlamıla hayata geçiren bir dayanışma kendini göstermiştir. Meydana gelen bu birliktelikten "Tarihsel Roman" denilen bir edebî alt tür ortaya çıkmıştır. Geçmişten izler taşıyor olması, bu tür anlatıları çekici kılarken, salt tarih anlatımının tekdüzeliğinden kaçınılarak kurgunun olanaklarından yararlanılması, anlatıya hem bir derinlik hem de zenginlik katmıştır. Böylece okurun dikkati dağılmadan, zevkli bir okuma süreci yaşaması sağlanmıştır. Bu melez yapılı kurgu anlayışına gösterilen ilgi, zamanla konuyla ilgili kalem oynatan yazarların ortaya çıkmasına zemin hazırlamıştır.

Daha çok siyasi kimliğiyle ve siyaset üzerine yazdığı kitaplarıyla tanınan Fransız yazar Dominique Baudis de bu kalemlerden biri olarak görülebilir. İnceleme konumuzu oluşturan, 2010 Prix Mediterranée ödülüne layık görülen ve yazarın şu ana kadarki tek tarihsel roman çalışması konumundaki Cebelitarık Âşıları (Les Amants de Gibraltar, 2010) ile Baudis'yi, esasen bu alt türün açık temsilcilerinden biri olarak nitelemek güç olsa da, çalışmanın bu alt türün bir örneğini oluşturduğunu söylemek yanlış olmayacaktır. Romanda tercih edilen zaman, bu zaman dilimde kullanılan uzamlar, her ikisinin içine yerleştirilen gerçek tarihî kişilikler ve anlatının daha ilgi çekici hale gelmesi için tüm bunların bir kurgu çerçevesinde bir araya getirilmiş olması bunun göstergesidir.

Aşk, hırs gibi duyguların; entrika, savaş gibi olguların öne çıktığı anlatıda gerçeklik ne tarihi metinlerde olduğu gibi katıksız yansitılır, ne de tamamen kurgunun ellerine bırakılarak çizgisinden saptırılır. Bu bakımdan kurgu ön planda olmakla birlikte ikisi arasında ölçülü bir denge kurulduğu söylenebilir. Dolayısıyla anlatılanların tarih disiplini açısından nesnel ve bilimsel bağlayıcılığı bulunmamaktadır.

Romanda VIII. yüzyılda Endülüs Emevi Devleti'nin kuruluşunun ilk adımını oluşturan Berberi asıllı Tarık bin Ziyad'ın önderliğinde Avrupa yönünden yapılan fetih harekâtı, kurgu ürünü olan bazı bilgiler eşliğinde, romanesk bir üslupla anlatılır. Anlatı, Doğu Roma imparatoru II. Iustinianos'un (II. Justinianos), Konstantinopolis'i fetih hayâlleri kuran Emevi halifesi Abdülmelik oğlu El-Velid'i engelleme ve ülkesini Arap istilasından korumak amacıyla öğretmeni ve sadık dostu Angelos eliyle hem Emevi Emiri Musa'yı hem de onun emrinde görev yapan Tanca valisi Tarık bin Ziyad'ı Hispania (Günümüzdeki adı İber Yarımadası) seferine ikna etme ve böylece halifenin dikkatini buraya yönlendirme çabaları üzerine kuruludur. Böylece zaman içinde El-Velid, Emir Musa ve Tarık'ın bir arzu 
çatışmasına dönüşecek olan düşman topraklarını İslâmlaştırma ülkülerinin karşısına II. Justinianos'un ülkesini ve halkını muhtemel bir istiladan koruma ülküsü yerleştirilerek romanın ana konusu oluşturulur. Ülkü-arzu çatışması yaşayan roman kişilerinin kimi zaman ortaklaşan, ama çoğu zaman çakışan duygu ve eylemleri çarpıcı biçimde yansıtılır.

Bir tarafta olay örgüsü bu şekilde biçimlenirken, diğer tarafta ana konudan tamamen bağımsız olmayan kurgusallığın ön planda olduğu bir başka konu işlenmektedir. Buna göre, Septe Adası'nın (Günümüzdeki adı Ceuta) yöneticisi Iulianos (Julianos) ve onun ölen Berberi eşi Kâhine'den olma kızı Florinda'nın, hem Hispania'da hüküm süren Vizigot kralı Witiza oğlu Agila'yı hem de Tarık'ı kendine âşık ederek onları tutku dolu bir serüvenin içine sürükleyişinden bahsedilir. Bununla birlikte genç kızın Emir Musa tarafından yıllar önce öldürülen annesinin intikamını alma arzusuyla giriştiği şehvet ve entrika dolu olayların anlatımı söz konusudur. Bu şekilde anlatı zenginleştirilerek tekdüzeliğin önüne geçmek hedeflenmiştir.

Bu bilgiler ışığında çalışmamızda öncelikle gerçek ve kurgunun birlikteliğini temsil eden tarihsel romanın ortaya çıkışından ve özelliklerinden bahsedilecek, ardından ülkü ve arzu kavramlarının çeşitli düşünürlerin gözünde nasıl bir değer taşıdığına ilişkin görüşlere yer verilecek ve son olarak Dominique Baudis'nin söz konusu tarihsel romanı, roman kahramanlarının uğruna canlarını bile vermekten geri durmayacakları ülküleri ile, yine en az onun kadar vazgeçilmez gördükleri arzuları arasında nasıl bir mücadele verdikleri konusundan hareketle tematik olarak incelenecektir.

\section{TARIHSEL ROMAN}

Tarihsel roman, uzun zamandır edebiyatçılar arasında tartışma konusu olan ve hakkında yapılan değerlendirmelerin heterojen yapıda olması nedeniyle üzerinde henüz uzlaşmanın sağlanamadığı edebî bir türdür. Değerlendirmelerde görülen bu ayrıksı yapı, aynı zamanda türün gerçek anlamını bulması yolunda ona destek olan birer sütun görevi görmüştür. Yapılan saptamalar her ne kadar çeşitlilik gösterse de, her birinin ortak bileşeni konumunda yer alan bazı noktalar da yok değildir. Dolayısıyla bu alt başlıkta ilkin tarihsel romanın nasıl bir tür olduğuna, kökenine, ortaya çıkışına ve bu anlayışı oluşturan temel yapı taşlarına değinilerek tarihsel romana ilişkin ortak somut bir çerçeve oluşturulmaya çalışılacaktır.

Zıtlıkların Uyumu kavramı edebiyatta çokça karşılaşılan bir ifadedir. Özellikle söz sanatlarının sıkça kullanıldığı şiir türünde görülen bu kavramın konumuz olan tarihsel romandaki karşıllı̆ı ne olabilir diye düşünüldüğünde, hiç kuşkusuz ilk akla gelen, imgelemde birbiriyle zıt anlamlar taşıyan "gerçek" ve "kurgu" kavramları olacaktır. Peki, somut, gerçekleşmiş olanı temsil eden "Tarih" ile; hayâli, fakat olması muhtemel olanı temsil eden "kurgu" kavramları birbirinin zıddı olduğu hissettirilmeden bir uyum içinde nasıl sunulabilir? İşte bu noktada tarihsel roman, kurgusal gerçekliğin somutlaşmış biçimi olarak karşımıza çıkmaktadır. Kurgulanan bu gerçeklik içinde "tarih, bir bilim dalı olmanın dışına çıkmış, güzel sanatlar ve onun kollarından biri olan edebiyata malzeme ve ilham kaynă̆ı olmuştur" (Argunşah, 2016, s. 10). Bu saptamanın dışında ünlü tarihçi Edward Hallett Carr, tarihin de kendi içinde bir yorumdan, bir anlatıdan ibaret olduğunu iddia eder. Nitekim ona göre tarihçi, olguları bir araya getirir, onlar arasından işine yarayanları seçer ve bu olgular üzerinden yorumda bulunur. Dolayısıyla Carr için tarih, olgular temelinde bir yorum işidir (Carr, 1987, s. 31). Fakat her şeye rağmen bu tespit, tarih ile romanı ayn düzleme 
taşımamaktadır. Tarih ve roman her ne kadar benzer yöntemler kullansa da, ilkinin "olmuşa" diğerinin "olabilire" dayanması aralarındaki en önemli farkı oluşturur.

Tarih ve roman arasındaki benzerlik ve farklılığa kısaca değinildikten sonra, tarihsel romandan bahsedilecek olursa, öncelikle tarihsel romanın ne ifade ettiği sorusuna yanit aramak doğru bir çıkış noktası olacaktır. Melez bir yapıda olmasına rağmen, tarihsel romanın da bir anlatı türü olduğunu özellikle belirtmek gerekir. Bununla birlikte bu melez yapı içinde tarih ve romanın iki eşit paydaş olmadığının de altını çizmek yararlı olacaktır. Nitekim tür için kullanılan "tarihsel roman/tarihî roman" ifadeleri, imgesel olarak daha çok roman özelliklerinin, yani kurgunun ön planda olduğu hissini uyandırmaktadır. Alman yazar Alfred Döblin'in "Tarihsel roman her şeyden önce bir romandır, tarih değil" sözü bu gerçeği yansıtmaktadır (aktaran: Göğebakan, 2004, s. 13). Benzer biçimde Hülya Argunşah'ın "roman, gerçeğin dille yeniden inşası yoludur. Bu yüzden tarihî romandaki gerçeklik, tarihî gerçeklikle yer değiş̧tirmiştir. Yazar tespit edilmiş tarihî gerçeklikten hareket etmiştir, fakat romanın kendine özgü değerler dünyasında yeni bir bütün meydana getirmiştir" şeklindeki tespiti de tarih-roman ilişkisinde kurgunun ağırlığına işaret etmektedir (Argunşah, 2016, s. 13). Böylece tarih bilimindeki ciddiyetin romanın esnekliğiyle yumuşatıldığı söylenebilir. Diğer taraftan bu tespit tarihsel romanın bilinen roman geleneğiyle birebir örtüştüğü anlamına da gelmemektedir. Dolayısıyla konu bütünlüğünün sağlanması için tarihsel romanın geleneksel romana göre farklılık gösteren özelliklerine değinmek yerinde olacaktır.

İlk olarak romanın tarihle olan bağı ele alınacak olursa, bunun bugünden yarına bir anda ortaya çıkmış bir şey olmadığı belirtilmelidir. Roman yazarının tarihle ilişkisi Antik Yunan'a kadar uzanan bir geçmişe dayanmaktadır. Tabi ki bu buluşma bugün bildiğimiz türde bir tarih-roman ilişkisini yansıtmamaktadır. Bunun temel nedeninin, yazı pratiğiyle ilgili olduğu söylenebilir. Nitekim söz konusu çağda hâkim olan yazı biçimi, düzyazıdan çok lirik anlatımın öne çıktığı şiirdir. Benzer durum Ortaçağ Fransa'sında gündemde olan ve modern romanın öncüleri konumunda yer alan epik içerikli kahramanlık şarkıları/destanları (Chanson de Roland, Chanson de Geste) için de geçerlidir. Fakat bunlar tarihsel romanın bugünkü konumu ve ağırlığı göz önüne alındığında, sadece tarih-roman ilişkisini ortaya koymak bakımından bir önem taşımaktadır. Hülya Argunşah modern çağ ile birlikte, tarihle bağı olduğu düşünülen mit kökenli anlatıların ve destanların, pozitif bilimlere önem veren zamanın insanını tatmin etmekten uzaklaştığını, bu nedenle meydana gelen boşluğun romanla, özellikle tarihsel romanla doldurulduğunu ileri sürer (Argunşah, 2016, s.11).

Anlatılanlar ışığında, genel tanımlamaya uyan tarihsel romanların daha çok XIX. yüzyılın başlarında ortaya çıktığı düşünülür. Bazı edebiyat bilimciler modern anlamdaki tarihsel romanın başlangıcını XVIII. yüzyıla dayandırsa da, birçoğunun özellikle Walter Scott'ın Waverley'ini (1814) tarihsel romanın ilk örneği olarak görmesiyle, XIX. yüzyıl tarihsel romanın başlangıç noktası olarak kabul edilmiştir. Scott'ın ortaya koyduğu bu yeni anlayış öylesine ilgi görmüştür ki, kendisinin ve kullandığı yöntemin ünü aynı yüzyıl içinde sadece İngiltere ile sınırlı kalmamış, hemen hemen tüm Avrupa'ya yayılmıştır.

Çoğu edebiyat bilimci gibi Walter Scott'ı bu türün mimarı olarak kabul edecek olursak, ondan önce türle ilişkili olduğu düşünülen mit eksenli Antik dönem ve Ortaçağ yapıtlarının, tarihsel roman kavramının anlamını bulmasını sağlayacak unsurları taşımadıkları görülecektir. Dolayısıyla yapısal olarak aralarında bir ilişki varmış gibi görünse de, tarihi konu edinen her edebî yaratıyı tarihsel roman olarak nitelemek doğru bir yaklaşım olmamakta ve bu adlandırma için tek başına yeterli bir neden oluşturmamaktadır. 
Hatta Macar araştırmacı ve kuramcı George Lukács, bu konuda XVII. ve XVIII. yüzyılın tarih konulu romanlarında dahi böyle bir amaç güdülmediğini iddia eder. Ona göre bu romanlar yalnızca dekor bakımından tarihseldir. Ne kahramanların ruh halleri, ne de olayların anlatım biçimi tarihsel roman yapısıyla bağdaşmamaktadır. Burada tarihin, sadece kahramanın içine yerleştirildiği bir fon olduğunu, yansıtılan tarihî dönemin gerçeğe yakın, aynı zamanda sanatsal bir kaygıyla aktarımının söz konusu olmadığını vurgular (Lukács, 2010, s. 21-22). Bu bakımdan Sadık Tural'a göre tarihsel roman yazarı bir yandan geçmişteki tarihsel bir dönemi ya da olayı, herhangi bir ideolojik amacın malzemesi yapmadan, çarpıtmadan, deyim yerindeyse taşıyıcı kolonlara zarar vermeden yansitmalı; öte yandan kaleme aldığı şeyin bir kurmaca olduğunu unutmadan edebî sanatsal anlayışı elden bırakmamalıdır (Tural, 1993, s. 69).

Scott'ın başlattığı anlayış, esasen Aydınlanmanın ve onun etkilerinin doruğa ulaştığı Fransız Devrimi'nin bir sonucu olarak ele alınabilir. Nitekim Lukács, tarihsel romanın oluşum ve gelişiminde Aydınlanma sürecinin önemli bir etkiye sahip olduğunu düşünür, çünkü ona göre Aydınlanma döneminde tarih yazımı üzerine yapılan çalışmalar, tarihsel romanın temelini oluşturur. Bu çalışmalar sonrasında yükselen toplumsal birlik anlayışı ve ulus olma bilinci, Fransız Devrimi'nin düşünsel alt yapısının oluşmasını sağlamıştır (Lukács, 2010, s. 23). Turgut Göğebakan da Lukacs gibi tarihsel romanın XIX. yüzyılda gerçek anlamını bulmasının, rastlantıya dayanmadığını ve Fransız Devrimi'nin bu noktada birincil derecede etkili olduğunu düşünür ve bu görüşünü şu şekilde açıklar:

\begin{abstract}
Fransız Devrimi ve Napolyon savaşları ulusçuluk dalgasını Avrupa'da neredeyse bir moda haline getirecektir. 1798 ve 1814 yilları arasında Avrupa'da her ülke şu ya da bu şekilde bir değişime maruz kalacaktır. Uluslar hem Napolyon işgallerinin uyandırdığı intikam duygusu, hem de dönemin genel karakteristiği haline gelen ulusçuluk akımı nedeniyle olayları o güne değin görülmemiş biçimde algzlamaya başladılar. Hem ilk tarihsel romanın 19. yüzyılda yazılmış, hem de tarihsel romanın en parlak dönemini 19. yüzyılda yaşamış olması bu bağlamda bir rastlantı değil, sözünü ettiğimiz sürecin bir sonucudur (Göğebakan, 2004, s. 19).
\end{abstract}

Yaşamın kendisi gibi edebiyatın durağan olmayan değişken yapısı, Scott'ın oluşturduğu tarihsel roman anlayışının da zaman içinde değişmesine neden olmuştur. Her yazarın tarihsel bilinç ve bakışındaki çeşitlilikten dolayı, genel tanımlamanın dışına çıkan tarihsel roman örnekleri de verilmiştir. Değişen bu yapı içinde, bir yandan özellikle tarihselliğin bir adım geriden geldiği yakın tarihli ya da çağdaş içerikli olayların anlatımı gündeme gelirken, diğer yandan yazınsallığın bir adım önden ilerlediği bir üslup tarihsel romanın sınırlarını genişletmeye başlar. Bazı noktalarda tanımla çelişmesi nedeniyle adlandırma sorununun yaşandığı bu tür çalışmalar için, genellikle "çağ romanı ya da çağdaş tarihsel roman" deyimi tercih edilmektedir (Göğebakan, 2004, s. 15-16).

XX. yüzyılın ikinci yarısından sonra, çağ romanı/çağdaş tarihsel roman nitelemesini de aşan tarihsel roman örnekleri görülmeye başlanmıştır. Bu romanlarda Scott'ta olduğu gibi sıradan kahramanların ve onların etrafında olup biten gerçek olayların aktarıldığı bir anlatıyı görmek pek mümkün değildir. Bu noktada Alman Hans Vilmar Geppert'in tarihsel romanla ilgili düşüncelerinin, Scott'ın anlayışına yeni bir boyut kazandırdığı söylenebilir. "Diğer Tarihsel Roman" olarak adlandırdığı bu yaklaşımda, Scott'ın romanlarında olduğu gibi tarihsel olay, anlatıda doğrudan ya da bir fon şeklinde yine yer almaktadır, fakat ondan farklı olarak yazarın özgürlük alanı alabildiğine geniş tutulur. Yani kurgunun ağır bastığı ve 
yazarın imgeleminin dizginlenmediği bir yapı söz konusudur. Yazara tanınan bu imtiyaz, zamanla yapısı oldukça değişecek tarihsel romanların ortaya çıkmasına zemin hazırlamıştır. Turgut Göğebakan Geppert'in geleneksel tarihsel romana oranla farklılık gösteren yaklaşımının iki temele dayandığını ileri sürer: İlki Scott'ın döneminde var olan koşullar ile yaşanılan dönem arasında belirgin bir uyuşmazlığın olması; diğeri değişen koşullar kadar birey algısında meydana gelen dönüşümle okur tipinin de başkalaşmış olması (Göğebakan, 2004, s. 20). Dolayısıyla zaman ve algıda görülen bu değişim, kimi zaman çarpıtılmış tarihsel gerçeklikle dahi karşı karşıya kalma ihtimalini artırmıştır. Özellikle XX. yüzyılın son çeyreğinde ortaya çıkan Umberto Eco gibi yazarların postmodern yazım uygulamalarında bunun örneklerini görmek mümkündür. "'Postmodern tarihî roman' diye adlandırlabilecek bu tür romanda tarihin ciddiyetinin dışına çıkılır; tarih oynanan, değ̌ş̧irilen, yeniden yazılan bir şey olur ve kurgu oldukça iddial bir boyut kazanır" (Argunşah, 2016, s. 22). Böylece konunun başında da dile getirildiği gibi tarihsel romanın tanımı, içeriği, sınırları bakımından neden hâlâ uzlaşılamayan bir roman türü olduğu gerçeği, yaşanılan bu değişim süreci üzerinden açıklık kazanmış olur.

Türün tarihsel gelişimi konusunda çizilen bu çerçevenin ardından, yapısal özelliklerine değinilecek olursa, türün bu adı taşımasının temelinde, tarihle olan ilişkisinin var olduğu açıktır, fakat burada ikinci bir soru karşımıza çıkmaktadır: Tarih, ama nasıl bir tarih? Yani geçmişte yaşanmış her olay, tarihsel romanın konusu olabilir mi? Tarihsel roman yazarının genellikle geçmişteki sorunlu olay ve dönemlere ilgi duyup konuların bunlar arasından seçmesi, bu sorunun yanıtı niteliğindedir. Dolayısıyla, tarihsel romanın yazım sürecinde tarihsel bilinç ve bakış belirleyici rol oynamaktadır. Bu çerçevede bir tarihsel roman ortaya koyabilmek için geçmişte iz bırakmış bir olayı gerçekliğe dair belirlenen temel kurallar çerçevesinde yazınsal süzgeçten geçirip edebî bir üslupla romana dâhil etmek tarihsel roman yazarının öncelikli görevidir. Buna rağmen bütün bunlar tarih konulu bir romana tarihsel roman diyebilmek için gerekli nedenler bütününü oluşturmamaktadır.

Konuya farklı bir pencereden bakmaya çalışan Sadık Tural, bu nedenlere bir yenisini ekler ve bir romanın tarihsel roman olabilmesini, söz konusu olay ya da durumun sonlanmış, zaman mührünü yemiş, hatta olayın etkilerinin dahi bitmiş olmasının gerekliliğine bağlar (Tural, 1992, s. 225). Bu ayrıntı, tarihsel romanı yine tarihi konu alan çă̆ romanlarından/ çağdaş tarihsel romanlardan ayıran temel özellik olarak kendini gösterir. Öte yandan bir tarihsel romanda olayın gerçekleştiği tarihle, yazar eliyle edebî bir nitelik kazandığı tarih arasında ne kadarlık bir zaman farkı olması gerektiği sorusu ise bir başka tartışma konusudur. Uygulama noktasında yazardan yazara çeşitlilik gösteren bir durum olsa da, türün öncüsü olarak kabul edilen Scott'ın yapıtları göz önüne alındığında, bu iki kutup arasında en az iki-üç kuşaklık yani hemen hemen 60-70 yıllık bir zaman aralığının bulunduğu görülür (Göğebakan, 2004, s. 16). Bu tercih değişmez bir kural olmadığından, her yazar kendi tarih bilincinde ve bakışında önem taşıyan olaylara ve dönemlere yönelebilmektedir. Burada uzlaşmaya varılan ve önemli olan nokta ise, tercih edilen olay ya da dönemin kriz niteliği taşımasıdır. Dolayısıyla bu saptamadan, sıradan olay ya da dönemlerin tarihsel romanın konusu olamayacağı sonucuna varılabilir.

Scott'ın tarihsel roman anlayışını böylesine belirleyici bir ölçüt haline getiren neden araştıııldığında, bunun yazarın tarihe bakışıyla doğru orantılı olduğu anlaşılır. Tarihi, tekdüze ve sıkıcı anlatımdan uzak yeni bir gözle değerlendirme ve yeni bir üslupla canlandırılma isteği, bunun en temel nedenidir. Scott'tan önceki tarih konulu romanlarda,

SEFAD, 2019; (42): 35-54 
geleneksel roman anlayışında görülen, olayların kendisi etrafında şekillendiği, tüm zorluklarla mücadele etmek zorunda kalan bir kahraman figürü bizi karşılamaktaydı. Bu durum Scott'la birlikte değişmiş, sadece romanın başkişisini değil, diğer bütün karakterleri içine alan bir değişim kendini göstermiştir. Anlatıda yer alan kişilerin çoğu, sıradan insanlardan oluşmaktadır artık. Buradaki amaç, tarihsel olayların sıradan insanın bakış açısıyla yansıtılmasıdır. David Skilton, Scott'ın bu yaklaşımını sıradan insanın bilinç düzeyini ve bakış açısını, romanın temel yapı taşı konumuna getirmek olarak yorumlar (Skilton, 1977, s. 93). Dolayısıyla Scott'a göre yaşanan olayların etkilerini tüm yönleriyle algılayabilmek, toplumda onları deneyimleyen alt tabakanın bilinç düzeyine inmekle ve yaşananlara onların gözünden bakmakla mümkün hale gelebilir. Toplumdaki alt tabakanın bilinç düzeyine ise, ancak olay örgüsünün sıradan insanlar üzerine kurulmasıyla erişilebilir. Böylece Scott, kendi döneminde ve sonrasında kaleme alınacak tarihsel romanların değerlendirilmesinde önemli bir başvuru kaynağı olmuştur.

Buraya kadar yapılan değerlendirmeler bir araya getirildiğinde, Döblin'in deyişinden, Lukács'ın tarihsel romanın kökenine, temel özelliklerine ilişkin düşüncelerinden, Scott'ın tarihsel roman anlayışından ve diğer araştırmacıların söylemlerinden yola çıkarak, her ne kadar zaman içinde birtakım değişiklikler yaşamış ve yaşayacak olsa da genel bir tarihsel roman tanımı yapmak mümkündür. Buna göre tarihsel roman, "kurgusal özelliklerin öne çıktığı; süreç ve etkileri bakımından tarihsel olarak kriz niteliği taşıyan, sonlanmış herhangi bir tarihsel dönem ya da olayın uzamla uyumlu biçimde hem olabildiğince gerçeğe yakın aktarıldığı hem de sanatsal bir üslupla yansıtma amacının güdüldüğü; konu edinilen dönem ya da olayın gerçekleştiği zaman ile kurgu yoluyla sanatsallaştığı zaman arasında en az ikiüç kuşaklık farkın bulunduğu; anlatıdaki kişilerin ana karakterlerle birlikte eşit düzeyde rol üstlendiği; kurgu ile gerçeğin uyum içinde bir araya geldiği melez yapılı bir roman türüdür" şeklinde tanımlanabilir.

\section{ÜLKÜ VE ARZU KAVRAMLARI ÜZERINNE}

Tarihsel roman hakkında yapılan bu genel değerlendirme ve tanımlamanın ardından, Baudit'nin edebî eserinde tematik inceleme ögesi olarak belirlenen ülkü ve arzu kavramlarına değinilerek incelemenin teorik alt yapısı tamamlanacaktır.

Konuya Platon'un görüşleriyle başlanacak olursa, Antik Çağ düşünürü, ünlü Devlet adlı yapıtında insan ruhunun üç ilkeden oluştuğunu dile getirir: akıl, irade ve istek. Bu üç ilkeden ilki insanı bilgi edinmek gibi yüce amaçları benimsemeye, diğeri duyguların yönetimine, sonuncusu ise yeme-içme, cinsel ilişki gibi isteklere yönlendirir (Platon, 1999, s. 436). Bu üç ilke arasında aklın üstün konumda olduğunu, diğer iki ilkenin onun kontrolünde hareket ettiğini ileri süren Platon, diğer taraftan ruh ve beden arasında bir kıyaslama yaparak ruhun beden karşısında yönetici konumda olduğunu belirtir. Bunu Phaidon başlıklı yapıtında "Ruh ve beden birlikte olduklarında Tanr bedene köleliği ve boyun eğmeyi, ruha ise komutanliğl ve efendiliği vermektedir" sözüyle açıklar (Platon, 2001, s. 80). Diğer bir deyişle ruhsuz beden bir anlam ifade etmeyeceği için, ruhun ihtiyaçlarının karşılanması büyük önem taşımaktadır. Platon, ruhun en önemli amacının sonsuzluğa ve gerçek mutluluğa karşıllk gelen ideaya ulaşmak olduğunu düşünür. Bu noktada akıl, bu amaca erişme konusunda birincil görev üstlenir. İrade, duyguları yönlendiren, bedene bağlı olan, ama akıldan bağımsız hareket etmeden akıl ile istekler arasında dengeleme rolünü üstlenmektedir. Son olarak istek, dizginleri aklın elinde olan, buna karşın bedene bağll, başı buyruk hareket etme eğiliminde, düşünmeden, yalnızca arzulayarak haz almaya odaklanan 
ve insanı idealardan uzaklaştıran bir güç merkezidir (Platon, 1997, s. 246). Dolayısıyla düşünürün Epinomis adlı yapıtında da belirttiği gibi ruhla özdeş olan akıl, ölümsüzlüğün; bedenle özdeş olan istek ise, faniliğin simgesidir (Platon, 1943, s. 23/78). Bu durumda ülkü için, ideaya ulaşma konusunda daha içerikli bir anlam taşıması nedeniyle, akıl ilkesinin ürünü olduğu ve kalıcllı̆̆ temsil ettiği; öte yandan arzu için ise, bedenî isteklerin ürünü olması nedeniyle, istek ilkesinin bir yansıması olduğu ve geçiciliği simgelediği söylenebilir. Buna göre her iki kavram da ruhun ilkelerine bağlıdır, fakat bu ilkelerin işlevleri bakımından farklılık göstermesi, kavramların konumlanışını da etkilemektedir.

Bir başka Antik Çağ düşünürü Aristoteles, konuya aklın kullanımı açısından yaklaşır. Ona göre akıl iki bölümden oluşur: rasyonel bölüm ve irrasyonel bölüm (Aristoteles, 2014, s. 88). Nefsine hâkim olarak gerçekleştirilen eylemler rasyonel aklı temsil ederken, tersi irrasyonel aklı simgeler. Bu noktada haz olgusuna değinerek konuyu genişletir ve bedensel ihtiyaçların söz konusu olduğu (yeme-içme, özellikle cinsel istek, vb.) durumlarda, nefse karşı konulamayacağından hareketle bunun bir zorunluluk olduğunu ve nefsine karşı koyamayarak bedenî hazzı yaşamak ve arzularını tatmin etmek isteyen kişilerin, toplum tarafından yadırgandığını ileri sürerken; zafer, onur, kazanç gibi olgular uğruna nefsine hâkim olamayarak duyulan hazzın, zorunlu olmayan, kişinin isteği ve çabası sonucunda elde edilebilecek olgulara dayandığını ve bu türden bir hazzın peşinde koşanların, toplum tarafından takdir edildiğini ifade eder (Aristoteles, 2014, s. 338-339). Aristoteles'in düşüncelerinden yola çıkarak, hem arzu hem de ülkü kavramlarını aklın irrasyonel bölümünde ortaya çıkan, fakat zorunlu olup olmamaları açısından değişkenlik gösteren unsurlar olarak görebilir, arzu kavramının zorunlu; ülkü kavramının ise zorunlu olmayan hazların bir yansıması olduğu sonucuna varılabilir.

Orta Çağ düşünürü olan Descartes'in bu konudaki düşüncelerine bakıldığında, Ruhun Tutkular adlı incelemesinde, insanı ruh ve bedenden oluşan bir varlık olarak tanımlar. Ruhu, düşünce temelinde ruhun eylemleri ve ruhun tutkuları şeklinde iki alt başlıkta ele alan düşünür, ruhun eylemlerini, doğrudan ruhumuzdan gelen istem (volonté), tutkuların ise algılar (perception) başlığı altında değerlendirir (Descartes,2016, s. 24). Descartes istemi de ilki ruhun kendinde cereyan eden, maddi olmayan bir nesneye ya da düşünceye yöneltilen eylemler; diğeri maddi olan ve bedenimizle yaptığımız eylemler şeklinde ikiye ayırır (Descartes, 2016, s. 24-25). Burada ülkü kavramı ruhta cereyan eden ve maddi olmayan bir amaç uğruna yapılan eylemler içerisinde düşünülecek olursa, onun istemin bir türevi olduğu söylenebilir. Ünlü düşünür, ruhun tutkuları başlığı altında açıkladığı algılar kavramını ise, bedenle ilişkilendirilenler ve ruhla ilişkilendirilenler şeklinde iki alt başlıkta toplar. Descartes'in deyimiyle "doğal iştahalar" (appétits naturels) olarak değerlendirilebilecek tutku ya da cinsel arzu, bedenimizle ilişkilendirilen algılar olarak görülebilir (Descartes, 2016, s. 29). Dolayısıyla ona göre ülkü ve arzu kavramları ruhun eylem ve tutkularından türemeleri nedeniyle köken itibariyle ruhla ilgili olan, fakat içerikleri ve imgesel göndergeleri bakımından ayrışan kavramlardır.

Son olarak değineceğimiz Aydınlanma düşünürü olan Kant ise, bu konudaki tanımlamalarını Tanrı, Ruh ve Özgürlük kavramları üzerinden yapmaya çalışır. Üçünün de soyut kavramlar olması saf teorik akılla anlaşılmalarını güçleştirir. Bu nedenle üçü için de geçerli olmakla birlikte, özellikle özgürlük kavramının somutlaşmasında, pratik akla başvurulması gerektiğini ileri sürer (Öktem, 2007, s. 12). Ona göre Tanrı yüceliği, ruh ölümsüzlügüu, özgürlük ise aklıyla hareket eden insanı temsil etmektedir. Diğer yandan 
özgürlük, pratik aklın eylemlerimizi simgeleyen genel ahlak yasalarıyla ne düzeyde uyumluluk gösterebildiğiyle doğru orantılı olarak şekillenmektedir. Ülker Öktem aklın iradeyle ilişkisinin bu noktada belirleyici rol oynayacağını "Varlik sebebimiz, ancak ahlaklı davranışlarda, aklın pratik alanda (ahlak alanında) kullanılmasında, kısacası aklın iradeyi yönetmesinde anlamını bulur; gerçeklik kazanır" sözüyle açılar (Öktem, 2007, s. 15). Dolayısıyla Platon'un oluşturduğu üç ilke içerisinde yönetici konumunda yer alan akıl, Kant için aynı zamanda "iyi ve kötünün ayırt edilmesini sağladığından, ahlaki yükümlülüklerin de temelidir" (Bezci, 2005, s. 51). Kant'a göre ahlak alanında "en yüksek iyi"yi elde eden insan, aynı zamanda ruhun ölümsüzlüğünü kavramış ve Tanrı'nın yüceliğine inanmış olur. Bu çerçeveden bakıldığında, ahlak yasalarının ve pratik aklın onayladığı bir düşünce/eylem olarak görülebilecek ülkü kavramı, yararlılık ve kalıcılık açısından değerlendirildiğinde olumlu bir anlam taşırken, çoğu zaman hem akılla hem de ahlaki yasalarla çelişen arzu kavramı olumsuz bir anlam içermektedir.

Adı geçen düşünürlerin görüşleri genel olarak değerlendirilecek olursa, her iki kavramın da çoğu zaman çıkış noktası bakımundan benzeştiği, fakat içeriksel olarak farklılık gösteren itkiler yoluyla ortaya çıktı̆̆ı söylenebilir. Buna göre ülkü kavramının, daha çok ruhsal ve düşünsel (ruh-akıl) itkilerin tahrikiyle vazgeçilemez amaçlar uğruna her şeyden vazgeçilebileceğini ifade eden yüce bir olguyu temsil ettiği; arzu kavramının ise, ruhsal/duyusal/bedenî (ruh-duygu-beden) dürtülerin gücüyle ortaya çıkan, genellikle iktidar, bencillik, intikam, hurs ve cinsel istek gibi duygu ve kavramlarla karşllik bulan olumsuz içerikli bir olguyu imlediği sonucuna varılabilir. Bu çerçevede öne sürülen düşünceler doğrultusunda yapılan çıkarımın yansımaları, anlatının temel yapı taşları arasında yer alan kişiler ve onların davranışları üzerinden yapılacak değerlendirmelerle inceleme konusu olan Cebelitarık Âşıkları başlıklı tarihsel romanda ortaya konulacaktır.

\section{KİŞİ VE OLAYLAR ÇERÇEVESINNDE ÜLKÜ VE ARZU KAVRAMLARI}

Konuya geçmeden önce olayların anlatım biçimine ilişkin kısa bir değerlendirme yapmak yerinde olacaktır. Nitekim okuma süreci tamamlandığında anlatılanların romanın kahramanlarından Justinianos'un sadık dostu Angelos tarafından aktarıldığı fark edilmektedir. Yüzyıllar önce gerçekleştiği bilinen olayların bir kişinin bakış açısından anlatılıyor olması, okuyucuda bir vakanüvis yaklaşımıyla kaleme alınmış vakayiname hissi uyandırmaktadır. Bunun varsayımdan öte bir gerçek olduğu ise, Angelos'un "Bu vakayiname bana verilen görevin hikâyesiydi" sözünden anlaşılmaktadır (Baudis, 2012, s. 210). Zira Angelos hemen hemen romanda anlatılan her olayın ya tanığı ya da olayın geçtiği bölgede bulunması nedeniyle gözlemcisi ve aktaranı konumundadır. Dolayısıyla bu yönüyle, anlatının ana karakteri konumunda olduğu söylenebilir. Buna karşın anlatıda yaşanmış olayların yanında, kurgusal ögelerin yoğun biçimde kullanılmış olması; çoğunlukla kahraman bakış açısına rastlanmakla birlikte tanrısal bakış açısına da başvurulması; kişiler arası eşit rol dağılımının sağlanmış olması, Angelos'la ilgili bu özel durumun tarihsel roman kurgusunun bir parçası olduğu gerçeğini ortaya koymaktadır. Böylece kurgusal gerçeklik kavramının güçlendirilmesine katkıda bulunulmuştur.

Bu kısa bilginin ardından inceleme konusu düşünüldügünde, genel olarak neredeyse anlatıda yer alan tüm karakterlerin birer ülküsü ve ruhsal/bedenî arzusunun olduğu gözlemlenir. Anlatı boyunca biri insanın aklını, diğeri gönlünü esir alan bu iki olgunun çatışması söz konusudur. İkisi arasında kalan roman kişilerinin ne kadar zor bir tercih sürecine girdikleri yaşadıkları gelgitler üzerinden anlatılırken, ülkünün karşı konulması zor 
da olsa, arzulardan bir adım önde ilerlediği görülmektedir. Nitekim ülkü, yüce amaçlar uğruna yapılan iş ve eylemleri temsil etmesi bakımından kalıcılığı simgelerken; arzu, süreli ruhsal/duyusal/bedenî istekler uğruna girişilen eylemlerle anılması nedeniyle geçiciliğe işaret etmektedir. Buna karşın anlatı boyunca gerçek hayatta olduğu gibi arzuların baskın geldiği durumlarla da karşılaşılmaktadır.

Roman, Doğu Roma İmparatorluğu tahtının varisi II. Justinianos'un yaşadıklarının anlatımıyla başlar. Buna göre II. Justinianos, düşman olarak gördüğü ve hükümdarlığ sırasında kendisini birtakım hilelerle alaşağı edip on yıllık sürgüne gönderdikten sonra zorla tahta geçen Leontios'a, sonrasında Leontios'un yerine geçip kendisine cephe alan Apsimaros'a (tarihteki ismi III. Teberius) karşı on yıl aradan sonra amansız bir taht mücadelesine girişir. II. Justinianos sürgün öncesi ve sonrası ortaya koyduğu iktidar ve intikam mücadelesinde izlediği yöntemlerle, arzu ve tutkularının esiri olmuş bir zalime dönüşmektedir. Hatta anlatıya göre 705 yılı Ocak ayında, para ve güç vaadiyle ikna ettiği Bulgarlar ve Kazakların desteğini alarak şehrin surlarına dayandığında, sadece düşmanları için değil Konstantinopolis halkı için de bir korku kaynağı olmuştur. Bu durum metinde "Kimse dışarn çımaya cesaret edemiyordu. Ama kentin ve insanların taş kesilmesinin sebebi ne rüzgârdı ne de dondurucu soğuk. Sebep korkuydu. Onlara soğuğu unutturan bir korku" ifadeleriyle dile getirilir (Baudis, 2012, s. 14). Dolayısıyla ruhunun her zerresinde hissettiği intikam duygusu ve kendisinden gasp edildiğini düşündüğü tahtı geri alma hırsı, burada arzunun biçim değiştirmiş iki unsuru olarak karşımıza çıkar. II. Justinianos'un yaşadıkları karşısında düşmanlarına ve ona bu süreçte destek olmayan halkına karşı duyduğu öfke, anlatıda şu şekilde ifade edilir:

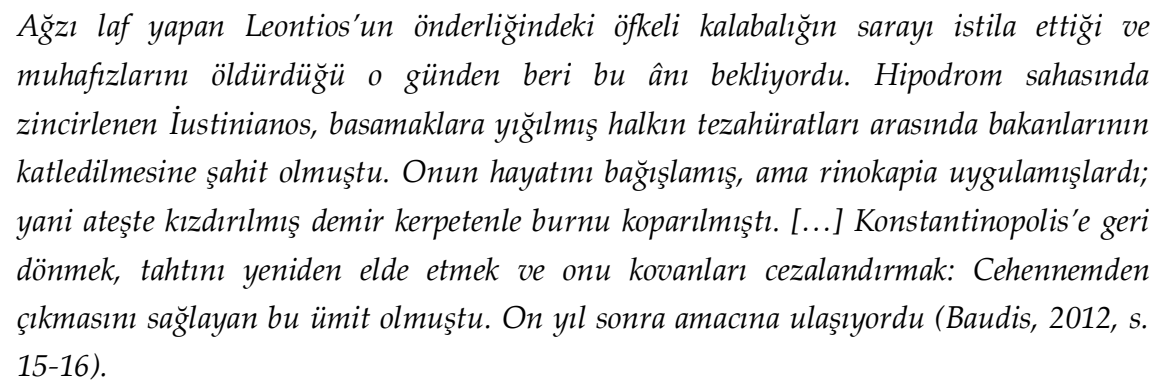

Öte yandan tahttan indirilirken yeniden tahta geçmesini engellemek adına uygulanan rinokapia'ya rağmen, sürgündeyken onunla evlenen ve kendisini tutkuyla seven Hazar hükümdarının kız kardeşi prenses Riva'ya karşı duyduğu tutku dolu aşk da arzunun görüldüğü bir başka noktadır. Daha önce intikam ve hırs duygularıyla kendini gösteren arzu kavramı, burada cinsel duyumsama olarak karşımıza çıkmaktadır. Bu durum aynı kişinin davranışlarında vücut bulan arzu değişimini gözler önüne sermesi bakımından önemlidir. II. Justinianos, Riva'ya duyduğu aşkı, onu şanlı atalarından I. Justinianos'un güzel ve çekici eşi Theodora'ya benzeterek, hatta tahta geçer geçmez adını II. Theodora şeklinde değiştirerek ortaya koyar. Riva'nın baş döndüren güzelliği karşısında cinsel dürtülerine yenik düşen Justinianos, bedenî hazları onunla tadar. Öte yandan Riva'nın ona duyduğu aşk, tahtından indirilmiş ve fiziksel eksikliğinden dolayı horlanmış olduğunu ona unutturur ve intikam yolunda ona güç verir. II. Justinianos'un, kendisine bütün bu hazları yaşatan ve içindeki intikam ateşini diri tutarak, ona yeniden yaşama sevinci aşılayan Riva hakkındaki düşünceleri şu sözlerle dile getirilir:

SEFAD, 2019; (42): 35-54 
Her duygusuyla onun esiri olmuştu. Gece gündüz onun bedenini seyretmek, gülmesini ya da şarkı söylemesini duymak saatlerce onu okşamak, teninin kokusunu içine çekmek, dudaklarının tadına bakmak arzusuyla doluydu. [...] Ondan önce hükümdarliğı boyunca saray hareminde tatmadığı zevk kalmamıştı. [...] Her ırktan kadın tanımıştı. Ona sonsuz çeşitlilikte hazlar tattırmışlardı. [...] Ama artık Riva'dan başka bir arzusu yoktu. [...] Riva onu okşarken, her yanım öperken, parmakları ve dudakları yüzünde uzun süre kalırken, İustinianos yüzünün biçimsizliğini unutuyordu (Baudis, 2012, s. 22).

Diğer taraftan imparatorluğun geleceğine ve güvenliğine tehdit oluşturacak durumlara karşı son derece hassas olması, vatansever bir hükümdar olduğunun işaretidir. II. Justinianos'un halkının huzuru, atalarının mirası olan topraklarının refahı ve din-kültür hayatının devamlılığı uğruna sergilediği bu yaklaşım, yüce bir değer taşıması bakımından onun olmazsa olmaz ülküsünü oluşturmaktadır. Bununla ilgili olarak şehrin surlarına dayandığı sırada askerlerine hitaben söylediği "Suçlu olan kent değil, ne surlarına ne de abide ve yapılarına dokunun. Öfkemizi gaspçlara ve onlara hizmet edenlere saklayalım" sözü de onun hassasiyetinin bir yansımasıdır (Baudis, 2012, s. 17). Bu anlamda taht mücadelesi sirasında gösterdiği intikam ve hirs dolu sert tutum yerini, zamanla ideal bir devlet yöneticisinin göstermesi gereken davranış ve düşüncelere bırakacaktır. Dolayısıyla karşı konulmaz duyguların etkisi altında girişilen bir mücadeleden, aklın egemen hale geldiği bir düzleme geçiş söz konusudur.

Roman kişilerinden bir diğeri olan, Justinianos'un çocukluğundan beri yanından ayrılmayan öğretmeni ve sadık dostu Angelos, anlatıda arzularına teslim olmayan, aklıyla hareket eden, ülkü sahibi bir devlet adamı olarak karşımıza çıkmaktadır. Sürgün yıllarında da onu yalnız bırakmayan Angelos, Justinianos'un hem hükümdarlığı döneminde hem de tahta yeniden geçtiği süreçte zalimce işler yaptığının farkındadır, fakat öte yandan onun yerine gelen iş bilmez kişilerin Justinianos'un hakkını gasp ettikleri düşüncesindedir. Onun yaptıklarından hoşnut olmadığını, bu nedenle yaşadıklarını yazarak bu histen kurtulmak istediğini "Doğru söylemem gerekirse bu aşırılıkları içimden kınıyordum. Şahit olmak bile istemediğim bu kanlı katliamlardan midem bulandığı için Saray'da kalıp yaşamakta olduğum olaylan kaleme almayı tercih etmiştim" diyerek ortaya koyar (Baudis, 2012, s. 29). Hükümdarının uyguladığ yöntemleri her ne kadar onaylamasa da, İmparatorluğun geleceği için onun yanında olması gerektiğine, böylece sürgün yıllarında yitirilen toprakların onun yönetimi altında geri alınabileceğine ve muhtemel tehlikelerin savuşturulabileceğine inanmaktadır. $\mathrm{Bu}$ anlamda danışmanlıktan istihbarat teşkilatı kurmaya, casusluktan arabuluculuğa varıncaya dek birçok vazifeyi üstlenmesi, ülküsü için neler yapabileceğinin göstergesidir.

Angelos tüm bu yaşananların ardından ilerde olacaklara ve üstleneceği görevlere işaret edercesine ayn dönemde İslâmiyet'i temsil eden Emeviler için "Müslümanların tehdidi ölümcül düzeye vardığı için, görevim iyice önem kazanmıştı. Elli yılı aşkın bir süredir Araplar imparatorluğu parçalayıp duruyorlardı. Topraklarımızın neredeyse yarısını almışlardı, yavaş yavaş Konstantinopolis'e yaklaşıyorlardı" ifadelerini kullanır (Baudis, 2012, s. 41). Bu hayati durum, onun Justinianos tarafından Konstantinopolis'e yapılacak muhtemel bir harekâtı engellemek üzere görevlendirilmesinin yolunu açacaktır. Arapları bu düşünceden vazgeçirmek, şehre saldırmak isteyen kavimleri geçmişte olduğu gibi altın ya da kıymetli eşyalarla ikna etmek kadar kolay değildir. Nitekim Müslümanlar için İslâm dininin yayılması her türlü zenginliğin üstünde sayılmaktadır. Beyrut üzerinden Şam'a geçerek, buradaki muhbiri Şam piskoposu Yusuf'un da yardımıyla dikkat çekmeden Halife El-Velid'in planlarını, neler 
yapabilecek güçte olduğunu öğrenmeye çalışır. Uzun süren çabalarının sonunda Konstantinopolis'e Ramazan ayında bir saldırı hazırlığı içinde olunduğunu öğrenen Angelos, aynı zamanda imparatorluğu kurtaracak altın değerinde bir planın peşindedir. Buna göre, Araplar Tanca'yı ve Herakles Sütunları Boğazı'nın (Günümüzdeki adı Cebelitarık Boğazı) güneyini ele geçirerek Avrupa'ya komşu olmuşlardı. Bu durumda Arapların Avrupa'ya Asya yerine Afrika'dan geçmesinin önünde bir engel bulunmamaktadır. Dolayısıyla Arapların bu fethe ikna edilmesinin zahmetsiz bir çözüm olabileceğini düşünür. Böylece Araplar hem Avrupa kabileleri ile girecekleri mücadelede zayıflayacak, hem de bu süreçte Konstantinopolis rahat bir nefes alacaktır. Hispania'yı İslâm toprağı yapmanın ve kutsal emanet olan Hz. Süleyman'ın Masası'nı Toledo'dan Şam'a getirip Halife'ye sunmanın, El-Velid'in komutanlarından Emir Musa ve Tarık bin Ziyad'ın en büyük hayâli olduğunu öğrenmesi ise, bu planı uygulama konusunda onu cesaretlendirir.

Emir Musa'nın El-Velid'in öfkesinden çekinerek Angelos'un teklifini kesin bir dille reddetmesi üzerine, Angelos Tarık üzerine yoğunlaşır. Sonunda El-Velid ve Emir Musa'dan habersiz büyük ölçüde işleyen bir plan çerçevesinde gerekli şartları oluşturarak Tarık'ı bu sefere ikna eder. Konstantinopolis'in fethine hazırlanan El-Velid'in ve Emir Musa'nın emriyle Septe Adası hükümdarı Julianos'tan fidye karşılığı alınan gemiler ve adamlarla birlikte Şam'a gelmesi istenen Tarık'ı ikna eden Angelos'un planı, Julianos'un karşı planıla boşa çıksa da, Got prensi Agila'nın basiretsizliği, Tarık'ın Hispania'yı fethetmesinin yolunu açar. Böylece Angelos bu zorlu görevden alnının akıyla çıkmayı ve ülkesini istiladan kurtarmayı başarır. Konstantinopolis'e döndüğünde, Justinianos öldürülmüş ve yerine Philippikos geçmiştir, bu nedenle Angelos zindana atılır. Ardından Philippikos'u komployla tahttan indirerek yerine geçen Anastasios tarafından zindandan çıkarılır ve imparatorluğa verdiği büyük hizmetlerden dolayı onurlandırılır. Benliğini bir kenara koyarak yüce bir amaç uğruna giriştiği bunca zorluk, Angelos'un ülküleri doğrultusunda hareket eden, bunun için her tehlikeyi göze alan bir kişilik olduğunu ortaya koymaktadır.

Romanda ülkü-arzu çatışmasının görüldüğü bir başka kişi ise, Halife Abdülmelik oğlu El-Velid'dir. Hz. Muhammed'in ölümüyle başlayan halifelik makamının altıncı varisi olan El-Velid, Müslümanların lideri olarak onları yönlendirebilme gücüne sahiptir. Anlatıya göre Halife'nin en önemli ülküsü Konstantinopolis'i fethetmek ve bu kadim şehri İslâm'la şereflendirmektir. Böylece Allah'ın ve Peygamber'inin dinine sahip çıkmakla kalmamış, onun yayılmasına da katkıda bulunmuş olacaktır. El-Velid'in bu ülküsü romanda "Konstantinopolis'in fethi. Babası bunu başaramamıştı, Allah'ın izniyle o başaracaktı. Dünyanın en büyük mabedi olan Aya Sofya, İslâm'ın en büyük camisi olacaktı" ifadeleriyle anlatılır (Baudis, 2012, s. 80). Bu hedef için donanmadan kara birliklerine varıncaya dek her türlü hazırlığı yapmaya başlar. Asya, Küçük Asya (Anadolu), Hindistan ve Afrika topraklarından sorumlu komutanlarla bir araya gelerek bu konudaki kararlılığını ortaya koyar. El-Velid'in Konstantinopolis harekâtının ardından sıraya koyduğu bir diğer ülküsü ise, yine İslâm'ı yaymak amaciyla Afrika üzerinden Hispania'ya geçmek ve buradaki kutsal emanetleri alarak İslâm'ın diğer dinler üzerindeki hâkimiyetini pekiştirmekti. Bu durum anlatıda "Mağrip üzerinden Hispania'ya saldıracak ve Kutsal Masa'yı Vizigotların elinden alıp Kudüs'e getirecekti. Vaftizci Yahya'nın başı Şam Camii'nde ve Hz. Süleyman'ın Masası da Kudüs'te olunca Hıristiyanlar ve Yahudiler kendi dinlerinin İslâmiyet'e dâhil olduğunu nihayet kabul edeceklerdi. ElVelid'in kendine vazife edindiği yüce görev buydu" sözleriyle açıklanır (Baudis, 2012, s. 80). Öte yandan El-Velid, bu planıla Avrupa içlerine ilerleme fırsatı bulacak, Asya ve Afrika 
yönünden yapılacak harekâtlarla İslâm'ı tüm dünyada hâkim kılacak, böylelikle kendisinin ve soyunun yüzyıllarca hatırlanmasını sağlayacaktır. Bu iki temel ülkü uğruna önüne çıkacak her engeli aşmaya kararlıdır. Bakış açısına göre değişmekle birlikte El-Velid'in koyduğu hedefler, onun Müslümanlar gözünde takdir edilmesini ve tarih boyunca anılmasını sağlayacağından, Halife'nin bu düşünceleri ülkü kavramı kapsamında değerlendirilebilir.

Anlatıya göre hükmettiği toprakları kaybetmek şöyle dursun, her geçen gün onlara yenilerini ekleme düşüncesinde olan El-Velid'in de arzularıyla hareket ettiği zamanlar olmaktadır. Mağrip Emiri Musa, Hispania'yı fethetmek için kendisinden izin istemeye geldiğinde, iktidarına ortak olacağı ve bu şerefin onun adıyla anılacağı düşüncesiyle onu şiddetle reddeder. Onun ikinci sıraya yerleştirdiği ülküsünün komutanlarından birinin zihninde uygulamaya hazır bir plan olarak öne sürülmesi, içindeki iktidar ateşini körükler. Oysaki temel amaç İslâm dinini tüm dünyaya yaymaktı, dolayısıyla bu isteğin olumlu karşılanması beklenirdi. Bunu İslâm halifesinin şanını yüceltmek için yapmak istediğini belirten Emir Musa'ya daha önce hakkında çıkan söylentileri hatırlatan El-Velid, Musa'nın bu talebini geri çevirir ve bu hakkı kendisine sakladığını "Benim şanım Avrupa'ya büyük kapıdan girmek olacak, Konstantinopolis'ten. Sonra gidip Hispania'dan Hz. Süleyman'ın Masası'nı alırız. Ama önce Aya Sofya. Tartışmayı kes! İstediğin adamlar ve gemileri alamayacağın gibi, elindeki savaş gemilerini de getireceksin" diyerek ortaya koyar (Baudis, 2012, s. 85). Böylece Emir Musa'nın bir çılgınlık yapmasının önüne geçmiş olur. Bu durum El-Velid'in arzu kavramı çerçevesinde değerlendirilebilecek iktidar hırsını göstermektedir.

Olaylara Emir Musa penceresinden bakıldığında, El-Velid'i haklı çıkaran bir manzarayla karşılaşılmaktadır. Emir, Halife engeline takılana kadar sunduğu planını uygulama eğilimindedir. Görünürdeki sebep, İslâm'1 yaymak gibi görünse de, aslında Emir'in hedefi öncelikle Hispania'yı fethederek nam kazanmak, oradan elde edilecek ganimetlere sahip olmak ve Kutsal Masa'yı Halife'ye götürerek Hispania Emirliğini almaktır. Fakat bu arzusunun, El-Velid'in ülküsüyle çatışabileceği ihtimalini hesaba katmamıştır. Emir Musa'nın arzularının yansıması olan zenginlik tutkusu ve Halife'nin bundan rahatsız oluşu metinde "çıktığı onca sefer onu zenginleştirmişti. Şam civarındaki bereketli topraklarm yarısına sahipti artık. [...] Ve her yeni sefer servetini arttriyordu. [...] Halife'nin kendisi bile sinirlenmekteydi" sözüyle ifade edilir (Baudis, 2012, s. 85). Bu durum onun güvenirliğine ilişkin bir şüphenin oluşmasına ve iktidar mücadelesi üzerinden karşıllklı arzu çatışmalarının yaşanmasına neden olmaktadır.

Fetih tertibinin Emir'in içinde bir ukde kaldığını bilen Angelos, çıkarlarının örtüşmesi nedeniyle Halife'ye rağmen onu Hispania seferine yönlendirmeye çalışır. Her ne kadar Angelos'u reddetse de, bu düşünce Emir Musa'nın zihnini sürekli işgal etmekte ve onu, bu onuru kendisinin yaşaması gerektiğine inandırmaktadır. Zira Angelos'un "o takdirde bu, Halife'nin başarısı olacak sizin değil. Oysa Hispania'nın ve Hz. Süleyman'ın Masası'nın ele geçirilmesi sizin zaferiniz olacak" sözleriyle karşılaşan Emir'in, bu gerçeği doğrulaması, fakat Halife'nin tepkisinden dolayı uygulamaya geçememesi, içini kemiren bu duygunun göstergesidir (Baudis, 2012, s. 135). Öte yandan Angelos ve Emir Musa arasında geçen bu görüşmede hazır bulunan Tarık bin Ziyad'ın Hispania'yı onun adına fethetme teklifine ise, tıpkı El-Velid gibi iktidar hırsına kapılırak sert bir dille karşı çıkar. Emir'in iktidar olma hırsıyla kendisine yakın gördüğü Tarık için aklından geçirdikleri anlatıda "Bu fethi erteleme mecburiyeti onu kudurtuyordu, Tark'ın bu zaferi onun elinden kapmasına ve Hz. Süleyman'ın 
Masası'nı Halife'ye götürme şerefine göz dikmesine tahammül edemiyordu" cümlesiyle dile getirilir (Baudis, 2012, s. 136). Dolayısıyla nefsini tatmin etmeye yönelik bu zenginlik tutkusu ve iktidar hırsı, Emir Musa'nın ülkü görünümlü arzularının daha ön planda olduğunu ortaya koymaktadır.

Emir'in olaylar karşısındaki tutumu incelendiğinde, görünürde ülkü gibi algılanan fakat aslında arzularının dışa vurumu olarak değerlendirilebilecek benzer davranışlar sergilediği gözlemlenebilir. Bu anlamda zenginlik ve iktidar hırsını çağrıştıran arzularının bir benzeri, Keyrevan'a inşa ettirdiği caminin yapım sürecinde de görülür. Müslümanlar gözünde bu tür mabetlerin önemi düşünüldüğünde, ilk bakışta Musa'nın bu mabedi yaptırmasının safi İslâmî bir hizmet düşüncesine dayandığı düşünülebilir. Burada toplum yararının gözetildiği varsayılırsa, bunun bir ülkü olarak değerlendirilmesi oldukça mümkündür, fakat Musa'nın caminin mimarıyla yaptığı konuşmalar sırada anlatıcı tarafından aktarılan "Keyrevan'ın şöhretinin sonsuza dek Kartaca'yı gölgede bırakmasını istiyor. [...] Boyutları ve güzelliğiyle tüm Afrika'da parlayacak bir cami sayesinde bu ihtişamı sağlayacaktı. [...] Şam'da El-Velid, inşaatın üç yılda bitirilmesini planlamıştl, Musa ondan önce bitirmek istiyordu" şeklindeki düşünceleri bunun tersi bir durumu göstermektedir (Baudis, 2012, s. 130). Nitekim Musa'nın asıl amacı, Halife El-Velid'in Şam'da yaptırdığı camiyi hem büyüklük hem de mimarisindeki özgünlük açısından geride bırakacak bir eser ortaya koymak ve bu şekilde gelecekte herkesçe bilinen biri olmaktır. Dolayısıyla arzu kavramı burada, önde olma ve kıskançlık duygularıyla karşımıza çıkmaktadır.

Ülkü ve arzu kavramları, romanın bir diğer önemli karakteri olan Tarık bin Ziyad üzerinden ele alınacak olursa, karakterin her iki kavrama da karşılık gelecek davranışlarının olduğu görülebilir. Tarık'ın en önemli ülküsü, El-Velid ve Emir Musa'da da karşılaşılan Hispania'nın fethi ve Kutsal Masa'nın Kudüs'e taşınmasıdır (Baudis, 2012, s. 73). Emir Musa tarafından teklifinin şiddetle reddedilmesi ve Emir'in kendisine hitaben söylediği "Allah'ın izniyle Müslümanlar bir gün Hispania'yı fethedecekler, ama onlara ben komuta edeceğim. Bir Berberi değil" cümlesi bir ayrımcılık içermesi nedeniyle Tarık'1 oldukça üzer (Baudis, 2012, s. 135). Bunu gören Angelos, onurunu koruması ve tasarladığı plan çerçevesinde Musa'ya ve ElVelid'e rağmen, bu yolda ilerlemesi konusunda Tarık'ı ikna eder. Planlarının Julianos tarafından öğrenilmesiyle uygulamada bazı değişiklikler olsa da, Tarık, Berberi savaşçılardan oluşturduğu ordusuyla Hispania kıyılarına çıkacaktır. Bu sırada askerlerini güdülemek amacıyla kullandığı "bu kez, zafer bizim olacak, Arapların emri altında olmayacağız. Halkımızın kahraman olduğunu, Peygamber'in sözünü taşımaya Araplar kadar layık olduğumuzu göstereceğiz" sözüyle fetih ülküsünü, aynı zamanda Emir Musa'ya olan tepkisini dolaylı olarak ortaya koyar (Baudis, 2012, s. 190-191). Ayrıca sefer gerçekleştikten sonra Tarık'ın Angelos'a yazdığı mektupta, çıkarma sırasında askerlerin geri dönmelerini engellemek için gemileri yakarak "Arkamızda deniz. Önümüzde düşman. Ya zafere, ya Cennet'e" ifadelerini kullandığını belirtmesi Tarık'ın ülküsüne bağlılığını göstermesi açısından önemlidir (Baudis, 2012, s. 214). Hatta önderliği ve cesareti nedeniyle Peygamber'in rüyasına geldiğini, onu fetihle müjdelediğini ve Herakles Sütunları'nın karşı kıyıda bulunan parçasının yeni adını ona bildirdiğini şu sözlerle açıklar:

\footnotetext{
Rüyamda Peygamber'i gördüm. Bana elini uzatıp şöyle diyordu: "Ilerle Tarı, kaderinde yazılanı yerine getir!" Hispania'yı fethetmemi, orada yaşayanlara İslâmiyet'i kabul ettirmemi ve Toledo'ya giderek Hz. Süleyman'ın Masası'n alı Kudüs'e götürmemi söylüyordu. Şunları da söyledi: “Karaya çıkacağın yerde çok büyük bir kaya var.
} 
Putperestlerin ona verdikleri adı yok say. İslâm'ın o zafer gününün anısına, bundan böyle tüm inananlar onu Tarık'ın Dağı (Cebel-i Tarık) olarak anacaklar" [...] artık Allah'ın arzusunu yerine getirdiğimi biliyorum (Baudis, 2012, s. 214).

Öte yandan Tarık'ın, ülküsünün karşısında yer alan iki önemli arzusu bulunmaktadır: ilki Julianos'un kızı Florinda'ya karşı hissettiği cinsel duyumsama; diğeri Got prensi Agila'ya beslediği kin ve kıskançlık. Tarık Florinda'ya öylesine bağlıdır ki, Tanca'ya geleceği haberini aldığı anda haremdeki eşlerine rağmen, onun için hazırlıklar yapar. Dolayısıyla Florinda'ya karşı büyük bir zaaf içindedir. Hatta onun bu zaafı, Angelos'un kimseye söylememesini istediği Hispania harekât planını çekiciliğini kullanan, asıl niyetini bilmediği Florinda'ya söylemesine, Florinda aracıllğıyla Julianos ve Agila'nın plandan haberdar olmasına, sonunda fethin bir süre gecikmesine neden olur. Burada arzunun bir bileşeni olan cinsel duyumsamanın Tarı'ın ülküsüne ulaşmasına zarar verdiği görülmektedir. Florinda'nın ihanetini öğrenmesiyle cinsel duyumsama, yerini yine arzunun bir türevi olan öfke ve kine bırakır. Tarık'ın Florinda'ya ve kendisine olan öfkesi "Florinda'nın ihaneti Tarık'ın içini kemiriyordu. Babasıyla konuşmasını kabul edebilirdi; ama Agila'yla birlik olup ona karşı entrika çevirmesine tahammül edemiyordu. [...] Florinda'nın geldiği gece ă̆zını sıkı tutamadığı için kendine kızıyordu" sözleriyle açıklanır (Baudis, 2012, s. 203). Böylece bu duygu, genç kızla ilişkisinde rakip gördüğü Vizigot prensi Agila'ya duyduğu kin ile bütünleşir. Fakat bu süreçte Agila'nın ve babası Witiza'nın, yine bir Vizigot prensi olan Rodrigo tarafından alt edilmesi ve Florinda'nın Rodrigo'ya esir düşmesi, Tarık'ın, eline geçen fırsatı değerlendirerek kininden ziyade yüceliği ve kalıcllığı temsil eden ülküsüne sarılmasını ve zafere ulaşmasını sağlar.

Kişiler arası ülkülerin arzulara evrilip çatışmaya dönüşmesi söz konusu olduğunda, iktidar hırsı, intikam, öfke, kıskançlık gibi duyguların ortaya çıtığına Justinianos/El-Velid, El-Velid/Emir Musa, Emir Musa/Tarık bin Ziyad, Tarık bin Ziyad/Florinda örneklerinde değinilmiş, fakat bu türden bir çatışmanın ne gibi sonuçlar doğurabileceğinden bahsedilmemişti. Bu anlamda anlatının sonunda Emir Musa ve Tarık arasında yaşananlar bu sorunun yanıtı niteliğindedir. Tarık'ın Hispania'ya sefer düzenlediğini öğrenen Emir Musa, bu onuru ona bırakmamak için harekete geçip, Tarık'ın peşine düşer. Bu beklenmedik durum karşısında Halife artık tamamen Hispania'nın fethine odaklanmak durumunda kalır. Halife'nin Hz. Süleyman'ın Masası'nı kim getirirse onu Emir tayin edeceğini belirtmesi üzerine, Musa da, Tarık da Kutsal Masa'yı kendilerinin bulduğunu iddia ederler. Bunun üzerine Halife onları huzuruna çağırır ve sonuçta Masa'yı bulanın Tarık olduğu anlaşılır, fakat Tarık'ın doğru söylediğini kanıtlamak için kurduğu plan kapsamında Masa'nın bütünlüğüne zarar vermesi, öte yandan Emir Musa'nın iktidar hırsıyla böyle büyük bir yalana teşebbüs etmesi her ikisinin de cezalandırılmalarına neden olur. Buna göre karşıllıklı bu çekişmenin bedelini Musa zenginliğiyle; Tarık ise özgürlüğüyle öder. Ortaya çıkan sonuç anlatıcı tarafından "Musa? Hayatta kalabilmek için sokaklarda dileniyordu. Tarkk? Bundan böyle adını taşıyacak Boğaz'ı geçen o kahraman, Şam'da gözaltında tutuluyordu, ülkesini ve yakınlarımı bir daha asla göremeyecekti" sözleriyle aktarılır (Baudis, 2012, s. 220). Bu durum eylemlerin arzular doğrultusunda gerçekleştirilmesi halinde, olumsuz sonuçlarla karşılaşılacağını göstermektedir. Öyle ki, bu örnekten, arzuların öncülük ettiği bir eylem söz konusu olduğunda, yücelik ve kalıcılığı temsil etmesine rağmen, ülkülerin dahi tüm değerini yitireceği anlaşılmaktadır. 
Romanın tek kadın karakteri konumunda yer alan, Bizanslı bir babadan ve Yahudi asıllı Berberi bir anneden dünyaya gelen Florinda, Emir Musa tarafından öldürülen annesi Kâhine gibi ahlâkî değerleri bir kenara bırakarak erkeklerle sınır tanımayan cinsel ilişkiler kurmaktan çekinmeyen bir kadın konumundadır. Bu tutumuyla görünürde olumsuz bir izlenim oluşturmasına karşın, vazgeçilmez gördüğü ülküsüne arzularını dâhil etmeyi başaran farklı bir kişilik olduğunu davranışlarıyla gösterir. Buna göre ahlâkî görünmeyen bu tutumunun altında onun için büyük anlam taşıyan bir ülküsü yatmaktadır. Florinda'nın uğruna her şeyi yapmayı göze aldığı ve bu yolda her şeyi mübah gördüğü, arzularla desteklediği ülküsü anlatıda "Kâhine'nin ölümünün intikamını almak, Araplara hak ettikleri dersi vermek ve Berberileri topraklarına ve özgürlüklerine kavuşturmak. [...] İntikamının zirve noktası Musa'nın ölümü olacaktı, [...] Böylelikle Florinda, Berberilerin kraliçesi olunca, Kâhine'nin uğruna can verdiği hayâlini gerçekleştirecekti" ifadeleriyle ortaya konur (Baudis, 2012, s. 146). Fakat bu ülkü, görüldüğü gibi arzuları temsil eden kin, öfke ve intikam duygularıyla yoğrulmuş bir yapıdadır. Hatta Tarık ve Agila, ülküsünü gerçekleştirmesinde onun için yalnızca birer basamak mesabesindedir. Bu anlamda Agila ona kraliçe olabilmesinin yolunu açacak bir anahtar rolü oynarken; Tarık ise, aslen bir Berberi olması ve ona karşı hissettiği tutku dolu aşk nedeniyle onun safında yer alabilecek bir savaşçı görevini üstlenecekti. Ülkülerin arzuların hâkimiyetine boyun eğdiği bu resimde, tıpkı Emir Musa ve Tarık gibi Florinda da amacına ulaşamamış, bunun da ötesinde Rodrigo'nun eline esir düşerek bir bilinmeze sürüklenmiştir.

Son olarak öldürülen eşi Kâhine ve annesinin yolunda ilerleyen kızı Florinda'nın tüm ahlâkî aşırılıklarına katlanan Julianos'a gelindiğinde, tıpkı Angelos gibi arzularından ziyade aklı ön plana alan, hayattaki her şeyden değerli gördügü ülküsü için çabalayan bir yöneticiyle karşı karşıya kalınmaktadır. Nitekim onun tek ülküsü, Arapların topraklarına gerçekleştirdiği saldırılar sırasında gösterdiği olağanüstü direniş neticesinde bağımsız bir prenslik olarak korumayı başardığı Septe Adası'nı canı pahasına savunmaktır. Bu noktada anlatının gerçek anlamda ülkü sahibi olan iki karakterinin düşüncelerindeki çatışmaya şahit olunmaktadır. Zira bir tarafta Angelos, Doğu Roma İmparatorluğu'nun güvenliğini sağlamak adına, tüm gücüyle Tarık üzerinden Halife'yi Hispania seferine zorlamaya çabalarken; diğer tarafta Julianos, Angelos'un planını öğrendikten sonra, fidye karşlığ Araplara verdiği gemilerden dolayı muhtemel Hispania seferinin her hâlükârda topraklarını ve halkını etkileyeceği düşüncesiyle buna engel olmaya çalışmaktadır. Anlatıda söz konusu bu tehlike şu sözlerle anlatılır: "Sonuç ne olursa olsun kendileri için kötü olacaktı. Ĕ̆ger girişim başarısız olursa Gotlar misilleme yapacaklar, bundan Septe de payına düşeni alacaktı, çünkü Tarık, Iulianos'un gemilerini kullanacaktı. Zayıf bir ihtimal de olsa, girişim başarnya ulaşacak olursa, Musa zaferi ve ganimetleri kendine mal etmek için Tarık'ın peşine düşecekti[...] ve Septe bağımsızlığın uzun süre koruyamayacaktı (Baudis, 2012, s. 155). Bu nedenle yaptığı hamlelerle Tarık'ı, Halife'nin ve Emir Musa'nın buyruğuna uymaya davet ederek bu güç durumdan siyrılmak ister, fakat çabalarına rağmen, değişen şartlar sonucu bu sefere engel olamaz. Dolayısıyla tüm bu yaşananlar Julianos'un son âna kadar ülküsüne sahip çıktı̆̆ının göstergesi niteliğindedir.

\section{SONUÇ}

Buraya kadar anlatılanlar ele alındığında sonuç olarak, romanda kullandığı tüm anlatı ögeleriyle Dominique Baudit'nin incelemeye konu olan edebî çalışmasının, edebiyat bilimcilerin ve araştırmacıların yaptığı değerlendirmeler neticesinde ortaya koyduğumuz

SEFAD, 2019; (42): 35-54 
tarihsel roman tanımında yer alan unsurları büyük oranda kapsadığı görülmüştür. $\mathrm{Bu}$ bakımdan tarihî gerçeklik ve kurgunun bir araya gelmesiyle ortaya çıkan bu bütünün, kurgusal gerçeklik deyimini somutlaştıran bir yapıya karşılık geldiği gözlenmiştir.

Bir tarihsel roman örneği olduğu açıkça görülen bu anlatıda, tematik açıdan incelenen ülkü ve arzu kavramlarının roman kişileri üzerindeki izdüşümünün farklı şekillerde ortaya çıtığ eşitlik, onur, toplumsal refah gibi söylem ve düşüncelerle; arzuların ise kişisel çıkarları önceleyen iktidar, bencillik, hırs, intikam, cinsel istek gibi duygu ve eylemlerle ilişkili olduğu sonucuna varılmıştır. Bir başka deyişle ülkü ve ülküyle bağlantılı aklî ve ruhsal amaçların olumlu sonuçlar doğurduğu; bunun aksine arzu ve arzuyla bağlantılı bedenî ve ruhsal isteklerin olumsuz bir imge oluşturduğu anlaşılmıştır. Roman kişilerinin başından geçenler ele alındığında, ülküleri arzularından baskın gelenlerin kazançlı çıktığı; arzuları ülkülerine galip gelenlerin ise zarara uğradığı bir tablo ortaya çıkmıştır. Bu durum bize yüceliği ve kalıcılığı simgeleyen ülkülere ulaşmak uğraştıııcı da olsa, sonuçları itibariyle ülkülerin arzulara tercih edilmesinin yararlı olacağı gerçeğini göstermiştir.

Yapılan tespit ve değerlendirmeler ışığında "en nihayetinde kurguyla yoğrulmuş bir tarihsel roman" diyerek geçiştirilebilecek bu edebî çalışmanın, yaşama dair böylesi önemli bir konuyu ana fikir olarak okura sunuyor olması, kurgu yoluyla aktarılan olayların, duygu ve düşüncelerin yalnızca romana özgü durumlar olmadığını, bunların gerçek hayattta da bir karşılığının olduğunu ya da olabileceğini ortaya koymuştur. Bu durum edebiyatın ne denli etkili bir yönlendirme aracı olduğunu göstermekle birlikte, yaşamla, yaşamsal deneyimlerle iç içe ve özdeş bir zemine oturduğunu bir kez daha gözler önüne sermiştir.

\section{SUMMARY}

The concept of fictional reality is a multifaceted issue that has been discussed in the literary world for a long time. Especially in XIX th century, some specialists thought that this concept, becoming a current issue with emergence of the movements of Realism and Naturalism, should exist in the content of the novel in order that the reader can find traces from himself or social life. In this context, rather than a narrative blended with the realities of the present; an understanding of fiction mixed with the realities of the past, experienced time, has started to come to the forefront. Therefore, a solidarity between "History" representing the experienced past and "Fiction" symbolizing a realisable future has emerged corresponding to the expression of fictional reality. Thanks to this association, a literary subgenre called "Historical Novel" has appeared. On the one hand, the fact that it carries traces from the past makes such narratives attractive and on the other hand, avoiding the uniformity of pure history presentation, has added both depth and richness to the narrative. From this point of view, history has been a source of inspiration for literature which is one of the branches of fine arts, by partially moving away from its scientific character. Thereby, it is necessary to underline that history and novel are not two equal shareholders. As a matter of fact, the expression "historical" used for this literary genre indicates that the features related to novel, namely fiction, are more distinct than history.

Considered that it contains historical elements, it is possible to base the emergence of historical novel upon Ancient Greece and Medieval heroic songs/epics. Nevertheless, it is accepted that modern historical novel in formal and contextual framework started with Walter Scott's novels in XIXth century. Because of all these features, the interest shown in this hybrid conception of fiction has spread from England to all over Europe and the number of 
writers who write on historical novel has increased day by day. This literary subgenre, whose popularity increased throughout the $X X^{\text {th }}$ century, has offered remarkable examples. In addition to this, the number of readers interested in this subgenre have been also augmenting.

Dominique Baudis, French writer, who is mostly known for his political identity and his books on politics, can be also seen as one of the novelists of this subgenre. Although it is difficult to describe Baudis as one of the clearest representatives of this subgenre, with Les Amants de Gibraltar (2010), the author's only historical novel work, which was awarded the 2010 Prix Mediterranée, it would not be wrong to say that the novel in question represents an example of this subgenre. The preferred time in the novel, the spaces used in that period, the real historical personalities embedded in both, and the fact that all these are brought together in a fiction framework to make the narrative more interesting have indicated rightfulness of this inference.

In narrative where feelings like love and ambition; facts such as intrigue and war come to the fore, reality is neither reflected purely as in historical texts, nor is it deviated from its aim by completely leaving it to the hands of fiction. In this respect, despite of the fact that the fiction is in the foreground, it can be said that there is a coherent balance between both. Therefore, there isn't an objective and scientific correlation between the events in the novel and historical discipline.

In the light of these informations, firstly, the emergence and characteristics of historical novel which represents the synergy of reality and fiction were explained in the study; then, opinions of various philosophers about ideal and desire concepts were mentioned; and finally, the historical novel in question of Dominique Baudis was examined thematically on the basis of the struggle between the indispensable ideals and the irresistible desires of the novel heroes.

At the end of the study, it was seen that Dominique Baudit's novel titled Les Amants de Gibraltar, in terms of narrative elements used in the novel, largely covered the elements in the definition of the historical novel shaped as a result of the evaluations made by the researchers. In this respect, it was observed that this whole which has occurred from the combination of historical reality and fiction corresponds to a structure that embodies the term of fictional reality.

In this study, where a narrative constituting an example of a historical novel was analysed, it was determined that the ideal and desire concepts thematically emerge in different forms. According to this, it was concluded that the ideal is related to positive discourses and thoughts such as justice, equality, honour, social welfare; on the contrary desire is connected with emotions and actions such as power, selfishness, ambition, revenge, sexual desire prioritising personal interests. In other words, while the ideal and mental and spiritual goals associated with the ideal bring positive results, desire and physical and spiritual requests associated with desire constitute a negative image. When the experiences of novel heroes were evaluated, it was seen that those who prevail their ideals over their desires make more profit and those who predominate their desires are in loss. This situation showed us that although it is difficult to reach the ideals symbolising the sublimity and permanence, it would be more beneficial for the individual to prefer ideals to desires in terms of results.

SEFAD, 2019; (42): 35-54 


\section{KAYNAKÇA}

Argunşah, H. (2016). Tarihî Roman. M. Argunşah (Ed.), Tarih ve Roman (s. 9-28). İstanbul: Kesit Yayınları.

Aristoteles (2014). Nikomakhos'a etik. (Z. Özcan, Çev.). Ankara: Sentez Yayınları.

Baudis, D. (2012). Cebelitarık âşıkları. (G. Akgerman, Çev.). İstanbul: Can Yayınları.

Bezci, B. (2005). Kant ve Hegel'in felsefesinde etik anlayışı. Sosyal Ekonomik Araştırmalar Dergisi, 9 (5), 48-61.

Carr, E. H. (2015). Tarih nedir?. (M. G. Gürtürk, Çev.). İletişim Yayınları: İstanbul.

Descartes (2016) Ruhun tutkuları. (M. Erşen, Çev.). Ankara: Say Yayınları.

Göğebakan, T. (2004). Tarihsel roman üzerine. Ankara: Akçağ Yayınları.

Lukács, G. (2010). Tarihsel roman. (İ. Doğan, Çev.). Ankara: Epos Yayınları.

Öktem Ü. (2007). Kant ahlakı. A.Ü. Dil ve Tarih-Coğrafya Fakültesi Felsefe Bölümü Dergisi, 18, 11-22.

Platon (1943). Epinomis. (A. Cemgil, Çev.). İstanbul: M.E.B. Yayınları.

Platon (1993). Phaidros. (H. Akverdi, Çev.). İstanbul: M.E.B. Yayınları.

Platon (1999). Devlet. (S. Eyüpoğlu, Çev.). İstanbul: İş Bankası Yayınları.

Platon (2001). Phaidon. (H. R. Atademir \& K. Yetkin, Çev.). İstanbul: Sosyal Yayınları.

Skilton, D. (1977). The English novel, Defoe to the Victorians. London: Barnes-Noble Publishers.

Tural, S. K. (1982). Tarihi roman ve Atsız'ın tarihi romanları üzerine düşünceler. H. Ağca, İ. Karakuş \& T. Türkdoğan (Ed.), Zamanın Elinden Tutmak (s. 220-261). İstanbul: Ötüken Yayınları.

Tural, S. K. (1993). Tarihî roman geleneği veya Cezmi. Doğumunun 150. Yılında Namık Kemal (s. 58-91). Ankara: Atatürk Kültür Merkezi Yayınları. 